\title{
Analisis Hubungan Sikap dengan Hasil Belajar Siswa di SMA Negeri 1 Sungai Penuh
}

\author{
Mashelin Wulandari ${ }^{1{ }^{1, *}}$, Nadia Yensi Febriana ${ }^{1)}$ \\ ${ }^{1)}$ Universitas Jambi \\ *mashelinwulandari@gmail.com
}

Abstrak: Hasil belajar siswa sangat erat kaitannya dengan sikap yang dimiliki siswa. Sikap merupakan gambaran perasaan suka atau tidaknya seseorang terhadap suatu objek. Penelitian ini bertujuan untuk dapat mengetahui bagaimana hubungan antara sikap dengan hasil belajar siswa kelas X di SMA Negeri 1 Sungai Penuh. Subjek dari penelitian yang dilakukan adalah siswa kelas X yang terdiri dari kelas X MIPA 1, X MIPA 2, dan X MIPA 3 dengan sampel berjumlah 60 siswa. Penelitian ini adalah penelitian kuantitatif dengan metode asosiatif kuantitatif jenis korelasional. Teknik pengumpulan data menggunakan angket dan lembar tes hasil belajar pada materi Hukum Gravitasi Newton. Data dianalisis menggunakan teknik statistik deskriptif dan dilakukan uji prasyarat serta uji korelasi data dengan bantuan SPSS. Hasil yang diperoleh dari penelitian ini yaitu, terdapat hubungan antara sikap yang dimiliki oleh siswa dengan hasil belajar yang diperolehnya. Hubungan ini dapat dilihat pada uji korelasi dimana nilai pada pearson correlation adalah $0,041<0,05$, sehingga Ho ditolak dan dinyatakan ada hubungan atau korelasi antara sikap dengan hasil belajar siswa. 90\% siswa dikatakan memiliki sikap yang baik dengan hasil belajar yang tinggi dan $8,3 \%$ siswa dikatakan memiliki sikap yang sangat baik dengan hasil belajar yang sangat tinggi.

Kata Kunci: Penelitian, Sikap, Hasil Belajar, Fisika.

\section{Pendahuluan}

Pendidikan tak lepas dari yang namanya belajar dan mengajar. Pendidikan merupakan proses mengembangkan kemampuan dan potensi dalam diri setiap individu. Sedangkan belajar dikatakan sebagai proses perubahan tingkah laku yang bertujuan untuk memperoleh tingkah laku baru yang lebih baik (Keke $\mathrm{T}$. Aritonang, 2008). Pendidikan juga merupakan upaya untuk menghasilkan suatu sumber daya yang berkualitas (Asrial, Syahrial, Kurniawan, \& Septiasari, 2019). Pendidikan memegang peran penting dalam kehidupan seseorang (Astalini, Kurniawan, \& Putri, 2018). Education is an activity that purpose of preparing students at the school (Kurniawan, Astalini, Darmaji, \& Melsayanti, 2019). Persiapan yang dimaksud adalah persiapan agar menjadi seseorang individu yang lebih baik dan lebih matang saat menempuh dunia kerja nantinya. Sehingga pendidikan dikatakan bagian integral dari kehidupan individu (Kurniawan, Astalini, \& Kurniawan, 2019). Education in Indonesia is well integrated and now requires further development (Maison, Darmaji, et al., 2018).

Ilmu pengetahuan secara umum dibedakan menjadi dua, yaitu ilmu pengetahuan alam (IPA) dan ilmu pengetahuan sosial (IPS). Ilmu pengetahuan alam atau yang disingkat IPA adalah ilmu yang mempelajari konsep di alam dan penerapannya dalam kehidupan sehari-hari (Dari, Nasih, Studi, Fisika, \& Jambi, 2019). Mata pelajaran IPA menjadi salah satu yang wajib dikuasi oleh siswa (Asrial, Syahrial, Kurniawan, \& Maretika, 2018). IPA di pelajari di SMA dengan klasifikasi yang lebih spesifik. Siswa SMA pemikirannya sedang dalam tahap masih berkembang (Astalini, Kurniawan, \& Sumaryanti, 2018). Salah satu mata pelajaran yang dapat menunjang proses perkembangannya adalah pelajaran fisika. Mata pelajaran fisika sering sekali dianggap sulit oleh siswa (Pasaribu, Hendri, \& Susanti, 2017). Fisika merupakan bagian pembelajaran ilmu pengetahuan alam yang menelaah suatu fenomena dialam dan konkret (Sholekah, 2020). Dengan pembelajaran fisika, siswa diharapkan 
bisa menerapkan konsep yang dipahami dalam kehidupan sehari-hari (Maison, Lestari, \& Widaningtyas, 2020). Aspek yang dinilai dalam pelajaran fisika tidak hanya koginitif dan psikomotor, tetapi juga afektif atau dikap (Maison, Astalini, Kurniawan, \& Sholihah, 2018).

Sikap merupakan suatu pikiran dan perasaan seseorang terhadap lingkungan yang sulit di ubah (Putra \& Wiza, 2019). Attitude is an aspect of being essential (Kurniawan, Astalini, Darmaji, et al., 2019). Attitudes influence behavior will lead to positive results (Jufrida, Kurniawan, Astalini, Darmaji, \& Kurniawan, 2019). Sikap ini terdiri dari perasaan suka maupun tidak suka. Sikap siswa terhadap pelajaran juga bergantung dengan bagaimana hubungan atau komunikai antara guru dan siswa (Asrial, Syahrial, Kurniawan, \& Septiasari, 2019). Dalam upaya pemecahan masalah, peserta didik harus memahami semua aturan yang relevan (Yulianci, Doyan, \& Febriyanti, 2019). Salah satu bentuk upaya yang dapat dilakukan ialah komunikasi dengan guru. Dengan komunikasi yang baik, maka problema dalam pembelajaran dapat diatasi (Asrial, Syahrial, Kurniawan, \& Amalina, 2019). Sehingga siswa memperoleh hasil yang baik dan sesuai dengan harapan dan tujuan pembelajaran.

Hasil belajar merupakan capaian prestasi yang diperoleh dari perubahan dalam suatu diri individu (Safira, Setyawan, \& Citrawati, 2020). Pandangan siswa terhadap pelajaran fisika bisa mempengaruhi hasil belajar yang dicapai siswa (Asrial, Syahrial, Kurniawan, \& Septiasari, 2019). Siswa yang tidak senang terhadap fisika dapat dilihat pada hasil belajarnya (Astalini, Kurniawan, Perdana, \& Pathoni, 2019).

Peneliti memilih melakukan penelitian tentang hubungan sikap dengan hasil belajar siswa pada materi hukum gravitasi newton di SMA Negeri 1 Sungai Penuh ini karena belum ditemukannya penelitian yang sama dengan penelitian peneliti ini. Sehingga peneliti tertarik untuk melaksanakan penelitian ini dengan harapan hasilnya dapat menjadi acuan dan referensi untuk peneliti lain ataupun guru dalam mengukur sikap dan hasil belajar siswa. Tujuan dari penelitian ini yaitu, untuk mengetahui hubungan sikap yang dimiliki oleh siswa dengan hasil belajar fisika yang diperolehnya.

\section{Metode}

Penelitian yang digunakan oleh peneliti adalah penelitian kuantitatif dengan metode asosiatif kuantitatif jenis korelasional. Penelitian kuantitatif ialah penelitian dimana data yang dihasilkan berupa angka dan analisis data menggunakan data statistik (Winarsunu, 2017). Sedangkan penelitian asosiatif merupakan penelitian yang dilakukan untuk melihat hubungan antara dua variabel atau lebih dalam suatu penelitian (Anshori \& Iswati, 2017). Penelitian ini bertempat di SMA Negeri 1 Sungai Penuh pada semester ganjil Tahun Ajaran 2020/2021. Sasaran penelitian adalah siswa kelas X di SMA Negeri 1 Sungai Penuh yang meliputi 3 kelas sebagai populasi penelitian. Populasi adalah suatu wilayah yang generalisasi dan terdiri dari objek maupun subjek yang memiliki kuantitas dan karakteristik tertentu (Jaya, 2019). Sedangkan sampel untuk mewakili populasi dari penelitian ini adalah 60 siswa/i dari ketiga kelas yang telah disebutkan sebelumnya.

Teknik pengumpulan data yang digunakan adalah menggunakan kuisioner/ angket dan lembar tes soal kepada siswa. Angket adalah sebuah teknik pengambilan data dengan disebarkan kepada responden kemudian dikembalikan lagi setelah selesai diisi (Hendri, Pramudya, Ika, \& Pratiwi, 2020) dengan tujuan untuk memperoleh data tentang objek yang diteliti. Instrumen angket yang digunakan diadopsi dari Rio Darmawangsa dalam penelitian Nirmala pada tahun 2020. Pada angket ini terdapat 25 butir pernyataan dengan 5 indikator dan terbagi menjadi 14 pernyataan yang positif dan 11 pernyataan yang negatif. Sedangkan lembar tes soal terdiri dari 25 soal pilihan ganda tentang materi Hukum Gravitasi Newton. Dalam kuisioner ini peneliti menggunakan pendekatan skala Likert. Skala Likert yaitu skala yang berfungsi sebagai alat ukur persepsi seseorang (Situmorang, 2010). Alternatif jawaban ada 4 pilihan, yaitu setuju, sangat setuju, tidak setuju, dan sangat tidak setuju dengan skala skor berbeda. Skala skor ini bertujuan untuk memperoleh data tentang efektifitas siswa (Priyadi, Maison, \& Kurniawan, 2015). Untuk tes yang berupa soal, alternatif jawaban ada 5 pilihan dengan jawaban benar diberi skor 1 dan jawaban salah diberikan skor 0 .

\section{Hasil dan Pembahasan}

Penelitian ini dilakakuan di SMA Negeri 1 Sungai Penuh selama 2 minggu pertengahan Oktober 2020 dengan sampel penelitian berjumlah 60 siswa. Instrument penelitian ini dibedakan menjadi instrument angket sikap siswa dan instrument tes soal yang berupa pilihan ganda. Pada angket sikap, skor yang diberikan kepada siswa pada pernyataan positif adalah 4 jika siswa memilih sangat setuju, 3 jika siswa memilih setuju, 2 jika siswa 
memilih tidak setuju, dan 1 jika memilih sangat tidak setuju. Sedangkan skor pada pernyataan negatif adalah 4 jika memilih sangat tidak setuju, 3 jika memilih tidak setuju, 2 jika memilih setuju, dan 1 jika memilih sangat setuju. Sedangkan pada tes soal, jika jawaban siswa benar maka mendapat skor 1 dan jawaban yang salah mendapat skor 0. Data hasil statistik deskriptif untuk angket sikap siswa yang diperoleh dapat ditunjukkan pada tabel 1.

Tabel 1. Data Hasil Statistik Deskriptif Angket Sikap Siswa

\begin{tabular}{cccccccccc}
\hline Angket & Rentang & Kategori & Mean & Median & Modus & Min & Max & $\%$ & $\mathrm{f}$ \\
\hline \multirow{4}{*}{ Sikap } & $25-43,75$ & Tidak Baik & & & & & & 0 & 0 \\
& $43,76-62,50$ & Kurang Baik & 73,883 & 74 & 74 & \multirow{2}{*}{62} & 84 & 1,7 & 1 \\
& $62,51-81,25$ & Baik & & & & & & 90 & 54 \\
& $81,26-100$ & Sangat Baik & & & & & & 8,3 & 5 \\
\hline
\end{tabular}

Sikap siswa terhadap mata pelajaran fisika dibedakan menjadi 2 jenis, yaitu sikap positif dan sikap negatif (Astalini, Kurniawan, Melsayanti, \& Destianti, 2018). Sikap ini diekspresikan dalam bentuk suka maupun tidak suka. Pengukuran sikap ini digunakan untuk melihat kemampuan yang ada pada individu terhadap suatu objek (Kurniawan, Astalini, \& Anggraini, 2018). Dari hasil penelitian sikap siswa yang telah dilakukan dengan 5 indikator, yaitu implikasi sosial dari fisika, sikap terhadap penyelidikan dalam fisika, normalitas ilmuwan fisika, adopsi dari sikap ilmiah dan kesenangan dalam belajar fisika 1 orang siswa memiliki sikap yang kurang baik, 54 orang siswa memiliki sikap yang baik, dan 5 orang siswa memiliki sikap yang sangat baik. Jika disajikan dalam bentuk persentase, maka 1,7\% siswa memiliki sikap yang kurang baik, 90\% siswa memiliki sikap yang baik, dan $8,3 \%$ siswa memiliki sikap yang sangat baik. Sedangkan pada skala skor statistik sikap siswa ini, skor yang paling rendah adalah 62 dan skor yang paling tinggi adalah 84 dengan skor rata-rata (mean) adalah 73,883 yang berarti bahwa rata-rata siswa memiliki sikap yang baik. Untuk nilai tengah (median) adalah 74 yang berarti sikap siswa berada pada kategori baik. Nilai yang paling sering muncul (modus) adalah 74, yang berarti banyak siswa memilih pada kategori baik. Data hasil statistik deskriptif ini menunjukkan bahwa sikap siswa kelas X bisa dikategorikan baik.

Ditinjau dari aspek sains, berdasarkan isu sosial karakter siswa adalah salah satu yang harus diupayakan dan dioptimalkan (Kurniawan, Astalini, Kurniawan, \& Pathoni, 2019). Salah satu upayanya yaitu dengan menganalisis hubungan sikap siswa terhadap hasil belajarnya. Prestasi belajar siswa dapat disebabkan oleh dua faktor. Faktor tersebut adalah faktor internal dan faktor eksternal. Faktor internal adalah faktor yang berasal dari dalam diri seorang individu, sedangkan faktor eksternal adalah faktor yang berasal dari luar diri seorang individu (Chotimah, Hendri, \& Rasmi, 2018). Faktor lain yang memengaruhi sikap siswa terhadap IPA, khususnya fisika adalah kurangnya fasilitas untuk melakukan kegiatan percobaan di sekolah sehingga siswa kesulitan untuk mengembangkan rasa ingin tahunya (Astalini \& Kurniawan, 2019). Hal ini jugalah yang akan mempengaruhi hasil belajar siswa.

Untuk memperoleh informasi mengenai sikap dan hasil belajar serta hubungan sikap dengan hasil belajar, maka perlu dilakukan uji yang disebut dengan uji asumsi. uji asumsi ini terdiri dari beberapa uji. Uji-uji tersebut terdiri dari uji normalitas, uji linearitas dan uji korelasi. Analisis dilakukannya uji asumsi bertujuan sebagai syarat untuk melakukan uji hipotesis (Nurvianti \& Syarkowi, 2018). Uji hipotesis dapat dilakukan dengan berdasarkan pada korelasi product moment (Perdana, Subiyantoro, \& Anggraini, 2019). Untuk menentukan uji hipotesis maka harus dilakukan uji prasyarat terlebih dahulu, untuk mengetahui apakah data bisa digunakan atau tidak. Uju ini terdiri dari 2 uji, yaitu uji normalitas dan uji linearitas. Jika kedua prasyarat terpenuhi maka uji data dapat dilakukan dengan menggunakan statistik parametrik. Tetapi jika kedua prasyaratnya tidak terpenuhi maka dapat digunakan statistik nonparametrik (Suciyati \& Mariamah, 2018).

Uji pertama adalah uji normalitas. Diimana uji normalitas berfungsi untuk mendapatkan informasi tentang distribusi data, yaitu apakah variabel-variabel data yang diperoleh berdistribusi secara normal ataupun tidak (Hendri et al., 2020). Uji ini diperlukan sebelum melakukan uji-uji yang lainnya dengan membuat asumsi bahwa nilai residualnya mengikuti distribusi normal sehingga uji statistiknya dikatakan valid. Namun, jika tidak valid maka statistik parametrik ini tidak dapat digunakan. Hal ini diperkuat dengan pernyataan bahwasanya uji normalitas juga diperlukan untuk mendapatkan informasi apakah syarat darri sampel yang representatif telah terpenuhi atau tidak terpenuhi (Sari, Sukestiyarno, \& Agoestanto, 2017). Hasil uji normalitas yang diperoleh dengan menggunakan bantuan IBM SPSS Statistic software dapat dilihat pada tabel 2. 
Tabel 2. Data Hasil Uji Normalitas

\begin{tabular}{ccccccc}
\hline & \multicolumn{3}{c}{ Kolmogorov-Smirnov $^{\mathrm{a}}$} & \multicolumn{3}{c}{ Shapiro-Wilk } \\
& Statistik & df & Sig. & Statistik & df & Sig. \\
\hline Angket &, 076 & 60 &, $200^{*}$ &, 977 & 60 &, 302 \\
Hasil Belajar &, 113 & 60 &, 055 &, 964 & 60 &, 072 \\
\hline
\end{tabular}

Syarat suatu data dikatakan berdistribusi normal adalah nilai $\operatorname{Sig}>0,05$. Berdasarkan hasil yang diperoleh pada penelitian yang telah dilakukan dan telah disajikan pada tabel 2, uji normalitas untuk angket sikap dan hasil belajar siswa yang didapatkan terlihat pada tabel bagian Kolmogrov-Smirnov ${ }^{\mathrm{a}}$. Kriteria untuk pengambilan keputusa pada uji normalitas ini adalah $\mathrm{H}_{\mathrm{o}}$ ditolak apabila nilai signifikansi Asymp. Sig (2-tailed) $<0,05$ yang artinya data berdistribusi secara tidak normal dan $\mathrm{H}_{\mathrm{o}}$ diterima ketika nilai signifikansi Asymp. Sig (2-tailed) $>0,05$ yang artinya data berdistribusi secara normal (Marfu'ah, Rudibyani, \& Sofya, 2013). Nilai signifikansi Asymp.Sig (2-tailed) untuk angket sikap adalah 0,200 dan nilai signifikansi untuk hasil belajar fisika adalah 0,055. Dengan membandingkan nilai Sig dengan nilai taraf signifikansi $(\alpha)$ pada tabel test statistic, maka diperoleh nilai signifikansi untuk angket sikap adalah 0,200>0,05 dan nilai sig hasil belajar fisika 0,055>0,05. Karena nilai sig yang diperoleh $>0,05$, maka dieroleh suatu kesimpulan bahwa data yang didapatkan telah dikategorikan berdistribusi secara normal, sehingga statistik parametrik ini dapat digunakan.

Setelah dilakukan uji normalitas, maka delanjutnya adalah melakukan uji Linearitas. Uji linearitas ini merupakan prosedur yang dilakukan untuk mengetahui status linearnya distribusi data penelitian (Winarsunu, 2017). Tujuan uji linearitas ini adalah untuk mendapatkan informasi apakah data memiliki hubungan yang linear atau tidak. Uji linearitas dilakukan untuk mengetahui apakah sifat linear yang ada antara dua variabel yang sedang diidentifikasikan secara teori itu telah cocok atau tidak terhadap hasil penelitian yang diperoleh (Duli, 2019). Uji linearitas dilakukan dengan menggunakan IBM SPSS Statistic software. Data hasil uji linearitas angket sikap dan hasil belajar fisika siswa dapat dilihat pada tabel 3.

Tabel 3. Data Hasil Uji Linearitas

\begin{tabular}{ccc}
\hline & Sig & Kesimpulan \\
\hline Hasil Belajar * Angket Sikap &, 669 & Linear \\
\hline
\end{tabular}

Berdasarkan data hasil uji linearitas sikap dengan hasil belajar yang dimiliki siswa kelas X di SMA Negeri 1 Sungai Penuh pada tabel 3, nilai signifikansi data adalah 0,669. Ini menunjukkan bahwa nilai signifikansi yang diperoleh lebih besar dibandingkan nilai taraf signifikansinya $(\alpha)$, dimana nilai taraf signifikansi adalah 0,05. Karena nilai sig $>\alpha$ atau 0,669>0,05, diperolehlah kesimpulan bahwa data bersifat linear.

Hasil uji sebelum melakukan uji hipotesis diperoleh bahwa data berdistribusi normal, serta bersifat linear maka selanjutnya dapat dilakukan uji korelasi (Nofrialdi, 2018). Uji korelasi bertujuan untuk mengetahui seberapa kuat hubungan yang dihasilkan antara suatu variabel bebas dengan suatu variabel terikatnya. Variabelvariabel ini terdiri dari variabel sikap yang dimiliki siswa terhadap mata pelajaran fiska dan variabel dari hasil belajar siswa terhadapa materi hukum gravitasi Newton. Signifikansi uji korelasi bisa diperoleh dengan dua cara, yaitu dengan cara membandinngkan koefisien korelasi dan tabel r Product Moment dan juga dengan uji t (Yusup, 2018). Uji korelasi ini dilakukan dengan bantuan dari IBM SPSS Statistic software. Kemudian data yang diperoleh dipindahkan kedalam tabel. Data hasil uji korelasi ini disajikan pada tabel 4.

Tabel 4. Data Hasil Uji Korelasi

\begin{tabular}{cccc}
\hline & & Sikap Siswa & Hasil Belajar Fisika \\
\hline \multirow{3}{*}{ Sikap Siswa } & Pearson Correlation & 1 &,$- 264^{*}$ \\
& Sig. (2-tailed) & &, 041 \\
& $\mathrm{~N}$ & 60 & 60 \\
\multirow{2}{*}{ Hasil Belajar Siswa } & Pearson Correlation &,$- 264^{*}$ & 1 \\
& Sig. (2-tailed) &, 041 & \\
& $\mathrm{~N}$ & 60 & 60 \\
\hline
\end{tabular}

*. Correlation is significant at the 0.05 level (2-tailed). 
Berdasarkan hasil dari uji korelasi atau correlation test yang telah dilakukan, maka diketahui bahwa nilai signifikansinya adalah 0,041 dimana taraf signifikansinya adalah $5 \%$ atau 0,05 . Ini mengindikasikan bahwa nilai sig < 0,05 atau 0,041<0,05. Karena nilai signifikansinya lebih kecil daripada nilai taraf signifikansinya, maka Ho ditolak dan Ha diterima. Maksudnya adalah terdapat hubungan antara sikap yang dimiliki oleh siswa dengan hasil belajar fisikanya. Sehingga dapat disimpulkan 90\% siswa atau 54 dari 60 orang siswa memiliki sikap yang baik dan $8,3 \%$ siswa atau 5 dari 60 orang siswa memiliki sikap yang sangat baik. Berdasarkan analisis korelasi Pearson correlation yang menyatakan bahwa nilai signifikansi $0,041<0,05$, maka Ho ditolak dan dapat dikatakan bahwa ada hubungan antara sikap siswa terhadap hasil belajar fisika siswa.

Penilaian sikap menjadi suatu penilaian yang penting dalam proses pembelajaran sekarang ini, karena sikap merupakan bentuk dari tingkah laku yang sifatnya umum dan sikap akan sangat berpengaruh pada hasil belajar siswa (Christina, Yennita, \& Syaril, 2014). Penanaman karakter kepada siswa bisa menjadi solusi agar siswa mempunyai sikap yang baik saat belajar, sehingga siswa bisa memperoleh hasil belajar yang baik pula. Karakter atau sikap yang lemah jika diikuti dengan hasil belajar yang tinggi akan percuma, begitupun sebaliknya dengan karakter atau sikap yang kuat jika tidak diikuti dengan hasil belajar yang baik juga percuma saja (Hendri et al., 2020). Dengan kata lain, hubungan sikap dengan hasil belajar yang ideal adalah sikap yang kuat dengan hasil belajar yang baik mencerminkan bahwa manusia itu berkualitas. Siswa yang memandang pelajaran fisika disekolah sebagai suatu pelajaran yang sulit dan rumit, maka siswa tersebut tidak akan senang pada saat belajar sehingga hasil belajarnya kurang baik. Sebaliknya, siswa yang memandang fisika sebagai pelajaran yang menyenangkan, maka akan senang dan bersemangat saat belajar sehingga hasil yang diperolehnya juga baik.

\section{Simpulan}

Dari hasil penelitian yang telah dilakukan, hubungan antara sikap dengan karakter siswa dapat dilihat dengan melakukan uji normalitas, uji linearitas, dan uji korelasi. Data yang diperoleh berdistribusi secara normal dan bersifat linear karena nilai $\operatorname{Sig}>\alpha$ dan mempunyai hubungan atau korelasi karena nilai $\operatorname{Sig}<\alpha$. Sehingga Ho ditolak dan hubungan antara sikap dengan hasil belajar siswa kelas X di SMA Negeri 1 Sungai Penuh pada materi Hukum Newton Gravitasi. Hubungan antara sikap dengan hasil belajar siswa ini adalah 90\% (54 dari 60 orang) siswa memiliki sikap yang baik dan hasil belajar yang tinggi dan 8,3\% (5 dari 60 orang) siswa memiliki sikap yang sangat baik dan hasil belajar yang sangat tinggi.

\section{Ucapan Terima Kasih}

Terima kasih yang sebesar-besarnya peneliti ucapkan kepada keluarga yang selalu mendukung, dosen pembimbing yang telah membrikan arahan, seluruh pihak SMA Negeri 1 Sungai Penuh yang telah mengizinkan dan memperkenankan peneliti melaksanakan penelitian, serta seluruh pihak yang telah membantu dan mempermudah urusan peneliti sehingga peneliti bisa menyelesaikan penelitian ini hingga akhir.

\section{Daftar Pustaka}

Anshori, M., \& Iswati, S. (2017). Metodologi Penelitian Kuantitatif. Surabaya: Airlangga University Press.

Asrial, A., Syahrial, S., Kurniawan, D. A., \& Septiasari, R. (2019). Hubungan Kompetensi Pedagogik Dengan Kompetensi IPA Mahasiswa Pendidikan Guru Sekolah Dasar [Relationship of Pedagogical Competence and Science Competency of Elementary School Teacher Education]. PEDAGOGIA: Jurnal Pendidikan, 8(2), 149-157. https://doi.org/0.21070/pedagogia.v8i2.1872

Asrial, Syahrial, Kurniawan, D. A., \& Amalina, N. (2019). Analisis Hubungan Kompetensi Bahasa Indonesia Terhadap Kompetensi Pedagogik Mahasiswa Pendidikan Guru Sekolah Dasar 1,2,3,4. Premiere Educandum: Jurnal Pendidikan Dasar Dan Pembelajaran, 9(1), 1-8. https://doi.org/10.25273/pe.v9i1.2832

Asrial, Syahrial, Kurniawan, D. A., \& Maretika, L. D. (2018). Analisis Kompetensi Pedagogik dan Kompetensi IPA terhadap Calon Guru Sekolah Dasar PGSD FKIP Universitas Jambi. Jurnal DIDIKA: Wahana Ilmiah Pendidikan Dasar, IV(2), 41-49.

Astalini, A., Kurniawan, D. A., Melsayanti, R., \& Destianti, A. (2018). Sikap Terhadap Mata Pelajaran IPA di SMP se-Kabupaten Muaro Jambi. Lentera Pendidikan: Jurnal Ilmu Tarbiyah Dan Keguruan, 21(2), 214. https://doi.org/10.24252/lp.2018v21n2i7 
Astalini, A., Kurniawan, D. A., \& Putri, A. D. (2018). Identifikasi Sikap Implikasi Sosial dari IPA, Ketertarikan Menambah Waktu Belajar IPA, dan Ketertarikan Berkarir Dibidang IPA Siswa SMP Se-Kabupaten Muaro Jambi. Jurnal Tarbiyah: Jurnal Ilmiah Kependidikan, 7(2), 93-108. https://doi.org/10.18592/tarbiyah.v7i2.2142

Astalini, A., Kurniawan, D. A., \& Sumaryanti, S. (2018). Sikap Siswa Terhadap Pelajaran Fisika di SMAN Kabupaten Batanghari. JIPF (Jurnal Ilmu Pendidikan Fisika), 3(2), 59. https://doi.org/10.26737/jipf.v3i2.694

Astalini, \& Kurniawan, D. A. (2019). Pengembangan Instrumen Sikap Siswa Sekolah Menengah Pertama Terhadap Mata Pelajaran IPA. Jurnal Pendidikan Sains (JPS), 07(1), 1-7.

Astalini, Kurniawan, D. A., Perdana, R., \& Pathoni, H. (2019). Identifikasi Sikap Peserta Didik terhadap Mata Pelajaran Fisika di Sekolah Menengah Atas Negeri 5 Kota Jambi. Unnes Physics Education Journal, 8(1).

Chotimah, C., Hendri, M., \& Rasmi, D. P. (2018). Penerapan LKS Berbasis Inkuiri Terbimbing pada Materi Listrik terhadap Hasil Belajar Siswa Kelas IX SMPN 22 Kota Jambi. Jurnal Penelitian Pembelajaran Fisika, 9(1), 36-39. https://doi.org/10.26877/jp2f.v9i1.2315

Christina, R. I., Yennita, \& Syaril. (2014). Hubungan Antara Sikap Terhadap Sains Dengan Hasil Belajar Fisika Siswa Kelas VIII SMPN 1 RETEH. Jurnal Online Mahasiswa Fakultas Keguruan Dan Ilmu Pendidikan Universitas Riau, 4(2), 1-11.

Dari, R. W., Nasih, N. R., Studi, P., Fisika, P., \& Jambi, U. (2019). Identifikasi Tingkat KPS Mahasiswa Praktikum Pembiasan Kaca Plan Paralel Menggunakan Panduan Praktikum Berbasis E-Modul. JIFP (Jurnal Fisika Dan Pembelajarannya), 3(2), 47-57.

Duli, N. (2019). Metodologi Penelitian Kuantitatif. Sleman: Depublish.

Hendri, M., Pramudya, L., Ika, N., \& Pratiwi, S. (2020). Analisis hubungan karakter semangat kebangsaan dengan hasil belajar siswa. Jurnal Pembangunan Dan Pendidikan: Fondasi Dan Aplikasi, 7(1), 1-8. https://doi.org/http://dx.doi.org/ 10.21831/jppfa.v7i1.25209

Jaya, I. (2019). Penerapan Statistik untuk Penelitian Pendidikan (pertama). Jakarta: 2019.

Jufrida, J., Kurniawan, W., Astalini, A., Darmaji, D., \& Kurniawan, D. A. (2019). S tudents' attitude and motivation in mathematical physics. International Journal of Evaluation and Research in Education (IJERE), 8(3), 401-408. https://doi.org/10.11591/ijere.v8i3.20253

Keke T. Aritonang. (2008). Minat dan Motivasi dalam Meningkatkan Hasil Belajar Siswa. Jurnal Pendidikan Penabur, (10), 11-21.

Kurniawan, D. A., Astalini, A., Darmaji, D., \& Melsayanti, R. (2019). Students' attitude towards natural sciences. International Journal of Evaluation and Research in Education (IJERE), 8(3), 455-460. https://doi.org/10.11591/ijere.v8i3.16395

Kurniawan, D. A., Astalini, A., Kurniawan, N., \& Pathoni, H. (2019). Analisis Korelasi Sikap Siswa dan Disiplin Siswa terhadap IPA pada Siswa SMP di Propinsi Jambi. Jurnal Pendidikan Fisika Dan Keilmuan (JPFK), 5(2), 59-71.

Kurniawan, D. A., Astalini, \& Anggraini, L. (2018). Evaluasi Sikap Siswa Smp Terhadap Ipa Di Kabupaten Muaro Jambi. Jurnal Ilmiah Didaktika, 19(1), 124-139.

Kurniawan, D. A., Astalini, \& Kurniawan, N. (2019). SIKAP SISWA TERHADAP PELAJARAN IPA Di SMP KABUPATEN MUARO JAMBI PROVINSI JAMBI. Curricula: Journal of Teaching and Learning, 4(3), 111127. https://doi.org/10.22216/jcc.2019.v4i3.4150

Maison, Astalini, Kurniawan, D. A., \& Sholihah, L. R. (2018). Deskripsi Sikap Siswa SMA Negeri Pada Mata Pelajaran Fisika. EDUSAINS, 10(1), 160-167.

Maison, Darmaji, Kurniawan, D. A., Astalini, Dewi, U. P., \& Kartina, L. (2018). Analysis of Science Process Skills in Physics Education Students. Jurnal Penelitian Dan Evaluasi Pendidikan, 51(1), 51. 
Maison, Lestari, N., \& Widaningtyas, A. (2020). Identifikasi Miskonsepsi Siswa pada Materi Usaha dan Energi. Jurnal Penelitian Pendidika IPA, 6(1). https://doi.org/10.29303/jppipa.v6i1.314

Marfu'ah, S., Rudibyani, R. B., \& Sofya, E. (2013). EFEKTIVITAS PROBLEM SOLVING UNTUKMENINGKATKAN KEMAMPUAN MENYIMPULKAN PADA MATERI ELEKTROLIT DAN NON-ELEKTROLIT. Jurnal Pendidikan Dan Pembelajaran Kimia, 4(1), 287-298.

Nofrialdi, I. (2018). Tingkat Kecemasan Matematika Siswa SMA Negeri 2 Kerinci Kelas X MIA Sebelum Menghadapi Tes Matematika Berdasarkan Gender dan Hubungannya dengan Hasil Belajar. Edumatika Jurnal Riset Pendidikan Matematika, 1(2), 11-20.

Nurvianti, I., \& Syarkowi, A. (2018). Penggunaan Komik pada Pembelajaran Fluida Statis di Kelas XI IPA SMA Negeri 2 Kota Jambi Tahun 2017. Jurnal Penelitian Pembelajaran Fisika, 9(1), 59-65. https://doi.org/10.26877/jp2f.v9i1.2124

Pasaribu, D. S., Hendri, M., \& Susanti, N. (2017). Upaya Meningkatkan Minat Dan Hasil Belajar Fisika Siswa Dengan Menggunakan Model Pembelajaran Talking Stick Pada Materi Listrik Dinamis Di Kelas X Sman 10 Muaro Jambi. Jurnal EduFisika, 02(01), 61-69.

Perdana, R., Subiyantoro, C., \& Anggraini, L. (2019). Sikap dan Motivasi Siswa Pada Pelajaran Fisika di Sekolah Menengah Atas Rahmat. Pancasakti Science Education Journal, 4(2), 128-136. https://doi.org/10.24905/psej.v4i2.1339

Priyadi, R., Maison, \& Kurniawan, W. (2015). Pengembangan Kuis Interaktif Pembelajaran Fisika Pada Materi Hukum Newton Tentang Gravitasi Dengan Menggunakan Program Wondersharequiz Creator 4.5.1. Repository Universitas Jambi, 1(1), 1-6.

Putra, D. S., \& Wiza, O. H. (2019). Analisis Sikap Siswa Terhadap Mata Pelajaran Fisika di SMA Ferdy Ferry Putra Kota Jambi. Unnes Physics Education Journal, 8(3).

Safira, C. A., Setyawan, A., \& Citrawati, T. (2020). Identifikasi Permasalahan Pembelajaran IPA Pada Siswa Kelas III SDN Buluh 3 Socah. Jurnal Pendidikan MIPA, 10, 23-29.

Sari, A. Q., Sukestiyarno, Y. L., \& Agoestanto, A. (2017). Batasan Prasyarat Uji Normalitas Dan Uji Homogenitas Pada Model Regresi Linear. Unnes Journal of Mathematics, 6(2), 168-177. https://doi.org/10.15294/ujm.v6i2.11887

Sholekah, A. W. (2020). Peningkatan Motivasi Dan Hasil Belajar IPA Materi Pencemaran Lingkungan Melalui Model PjBL Siswa Kelas VII SMPN 9 Salatiga. Jurnal Pendidikan MIPA, 10, 16-22.

Situmorang, S. H. (2010). Analisis Data: untuk Riset Manajemen dan Bisnis. Medan: USU Press.

Suciyati, \& Mariamah. (2018). Hubungan antara Minat Belajar dengan Hasil Belajar Matematika pada Siswa Kelas V SD Negeri 04 Sila. Jurnal Pendidikan MIPA, 8(2), 142-149. https://doi.org/10.37630/jpm.v8i2.265

Winarsunu, T. (2017). Statistik dalam Penelitian Psikologi dan Pendidikan (Pertama). Malang: Universitas Muhammadiyah Malang.

Yulianci, S., Doyan, A., \& Febriyanti, F. (2019). Pengaruh Gaya Belajar Terhadap Penguasaan Konsep Fisika Siswa Pada Materi Besaran dan Pengukuran. Jurnal Pendidikan MIPA, 9(2), 123-127.

Yusup, F. (2018). Uji Validitas dan Reliabilitas Instrumen Penelitian Kuantitatif. Jurnal Tarbiyah: Jurnal Ilmiah Kependidikan, 7(1), 17-23. 